\title{
PENGARUH PENGGUNAAN MODEL PEMBELAJARAN SNOWBALL THROWING TERHADAP KETERAMPILAN MENULIS RESENSI CERPEN SISWA KELAS XI IPA SMA NEGERI 9 KOTA JAMBI
}

\author{
Novi Yolanda Dwi Sapitri ${ }^{1}$ \\ Program Studi Pendidikan Bahasa dan Sastra Indonesia, \\ Fakultas Keguruan dan Ilmu Pendidikan, Universitas Batanghari, \\ Jambi
}

\section{Noviyolanda43@gmail.com}

\begin{abstract}
The purpose of this research is to find out the effect of using snowball throwing learning model towards students' short story writing ability at class XI IPA SMA Negeri 9 Kota Jambi Academic year 2018/2019. The method of this research is quasi-experiment with quantitative approach which is used to measure the short story writing ability objectively. From the result of the research, it can be presented that the mean score of students' post-test of experiment class is 83 and control class is 75.8. The normality test which is taken from expermient class score is 0,095 >0,05 and control class score is 0,057 $>0,05$. Meanwhile the homogeneity test is significant in which $F 0,439>$ from significance level $(\alpha=0,05)$. The result of hypothesis testing is the value of $t_{\text {count }} 4,045>$ $t_{\text {table }} 2,000$ so $H_{o}$ is rejected and $H_{a}$ is accepted. Thus, it can be concluded that there is a difference of students' learning by using snowball throwing and conventional media. The students who used snowball got higher score compared with the students who used conventional media.
\end{abstract}

Keywords: Writing Short Story Review, Snowball Throwing Model

1 Mahasiawa Program Studi Pendidikan Bahasa dan Sastra Indonesia, Fakultas Keguruan dan Ilmu Pendidikan, Universitas Batanghari Jambi

Pengaruh Penggunaan Model Pembelajaran Snowball Throwing terhadap Keterampilan Menulis Resensi Cerpen Siswa Kelas XI IPA SMA Negeri 9 Kota Jambi 


\section{PENDAHULUAN}

Pendidikan merupakan salah satu pilar kehidupan bangsa. Pendidikan merupakan kebutuhan manusia sepanjang hayat. Kehidupan manusia selalu berubah sesuai dengan perkembangan zaman. Pendidikan bertujuan untuk mencerdaskan kehidupan bangsa. Menurut Rahima dan Erlina Zahar "Setiap warga negara berhak memperoleh pendidikan yang bermutu sesuai dengan minat dan bakat yang dimilikinya tanpa memandang status sosial, ras, etnis, agama, dan gender" (2008:25). Pemerintah mengupayakan berbagai cara untuk mencerdaskan kehidupan bangsa. Upaya pemerintah dalam mencerdaskan kehidupan bangsa di antaranya dengan menyelenggarakan pembelajaran di sekolah.

Bahasa Indonesia merupakan salah satu mata pelajaran yang dipelajari di sekolah. Pembelajaran bahasa Indonesia merupakan pembelajaran yang tak kalah pentingnya dengan pembelajaran lainnya di sekolah. Mata pelajaran ini bertujuan untuk mengajarkan berbagai ranah keilmuan bahasa dan juga keterampilan berbahasa (Setia, Erlina Zahar, Ade Rahima, 2018:184). Pembelajaran Bahasa dari askpek keterampilan berbahasa bertujuan agar siswa mampu menggunakan bahasa Indonesia dengan baik dan benar terutama dapat berkomunikasi, baik komunikasi secara lisan maupun komunikasi tertulis.

Selain itu, pembelajaran bahasa Indonesia diarahkan untuk meningkatkan kemampuan peserta didik berkomunikasi menggunakan bahasa Indonesia dengan baik dan benar, baik secara lisan maupun tulisan (Puspita, dkk., 2019: 105). Pembelajaran Bahasa Indonesia di sekolah mengajarkan berbagai keterampilan berbahasa yang dikenal dengan language skill. Pembelajaran keterampilan berbahasa terdiri dari empat ranting keterampilan. Ada keterampilan menyimak, keterampilan berbicara, keterampilan membaca dan keterampilan menulis. Rofii dkk. (2019A) "Writing skill is one of four language skills that must be mastered by students (Keterampilan menulis merupakan salah satu dari empat keterampilan berbahasa yang harus dikuasai oleh siswa). Pembelajaran keterampilan menulis akan menjadikan siswa terampil dalam menulis.

"Keterampilan menulis merupakan salah satu keterampilan berbahasa yang produktif dan ekspresif yang dipergunakan untuk berkomunikasi secara tidak langsung dan tidak secara tatap muka dengan pihak lain" (Tarigan, 2008: 3). Rofii dkk. (2018) mengatakan Writing is a complex activity requiring extensive and comprehensive knowledge (Menulis adalah kegiatan kompleks yang membutuhkan pengetahuan yang luas dan mendalam). Keterampilan menulis sangat penting bagi setiap siswa. Siswa sebagai penulis nantinya perlu memiliki banyak ide, ilmu pengetahuan dan pengalaman hidup. Hal ini merupakan modal dasar yang harus dimiliki dalam kegiatan menulis. Di samping modal dasar itu, siswa nantinya harus menguasai banyak perbendaharaan kata untuk menyampaikan ide-ide, pengetahuan, serta pengalaman yang dimiliki.

Salah satu pembelajaran keterampilan menulis yang diajarkan di Sekolah Menengah Atas (SMA) adalah pembelajaran menulis resensi cerpen. Pembelajaran menulis menulis resensi cerpen diajarkan agar siswa mampu menyusun sebuah tulisan ringkas yang memiliki kesatuan atau kepaduan yang logis. Tujuan pembelajaran menulis menulis resensi cerpen agar siswa 
mampu menggembangkan kemampuan meresensi dengan baik.

Keterampilan menulis resensi cerpen terdapat dalam Kurikulum 2013 tingkat Sekolah Menengah Atas (SMA) kelas XI. Sesuai dengan Kurikulum 2013 yang terdapat pada buku Lembar Kerja Siswa (LKS) dan buku pelajaran guru dan siswa, maka yang menjadi kompetensi dasar pembelajaran menulis resensi cerpen yaitu kompetensi dasar 4.17 mengkonstruksi sebuah resensi dari buku kumpulan cerpen atau novel yang sudah dibaca. Pembelajaran menulis resensi dari kumpulan cerpen atau novel dituangkan dalam bentuk tulisan dengan tujuan untuk mengkonstruksi sebuah resensi dari cerpen. Kompetensi dasar 4.17.1 meresensi sebuah cerpen. Mengkonstruksi dalam hal ini dimaksudkan adalah siswa diharapkan mampu membangun sebuah resensi dari cerpen dan dituangkan dalam bentuk tulisan. Menulis resensi bermanfaat agar siswa terlatih dalam memberikan penilaian secara kritis terhadap bahan bacaan yang dibacanya. Maka dari itu, dalam hal ini dibutuhkan suatu proses pembelajaran dengan menggunakan model pembelajaran agar tujuan pembelajaran dapat tercapai.

Salah satu upaya yang dapat digunakan untuk mewujudkan pembelajaran efektif dalam mengoptimalkan hasil belajar, yakni dengan cara menggunakan model pembelajaran (Rofii dkk., 2019B). Salah satunya adalah model pembelajaran Snowball throwing. "Snowball throwing disebut juga model pembelajaran gelundungan bola salju. Model pembelajaran ini melatih siswa untuk lebih tanggap menerima pesan dari siswa lainnya dalam bentuk bola salju yang terbuat dari kertas dan menyampaikan pesan tersebut kepada temannya dalam satu kelompok" (Saminanto, 2010: 37).

Pelaksanaan pembelajaran dengan model snowball throwing melalui beberapa langkah. Langkah model snowball throwing didahului dengan guru menyampaikan materi yang akan disajikan. Selanjutnya siswa diminta untuk berkelompok. Masing-masing anggota kelompok membuat sebuah pertanyaan pada selembaran kertas yang dibentuk seperti bola. Kemudian bola kertas dilemparkan kepada siswa lainnyauntuk mendapatkan jawaban selama durasi waktu yang ditentukan. Masing-masing siswa menjawab pertanyaan dari bola yang diperoleh. Model pembelajaran ini ditekankan pada kemampuan siswa untuk merumuskan suatu pertanyaan tentang materi pembelajaran yang disajikan. Kemampuan siswa dalam bekerja sama dengan teman maupun kemampuan individunya juga dapat diukur melalui model pembelajaran ini.

Penerapan model pembelajaran ini juga akan menggali kreatifitas siswa untuk menuliskan pertanyaan dan menjawab pertanyaan sekaligus. Tipe model pembelajaran ini memadukan pendekatan komunikatif, integratif, dan keterampilan proses. Dalam artian bahwa model pembelajaran snowball throwing dapat mendorong siswa untuk berpikir dan bergerak aktif selama proses pembelajaran sehingga kualitas serta tujuan pembelajaran dapat tercapai dengan baik sehingga akan meningkatkan hasil belajar siswa.

Berdasarkan hasil wawancara singkat dengan guru bahasa Indonesia yaitu Bapak Drs. Syahril, diperoleh informasi bahwa guru bahasa Indonesia di sekolah tersebut belum menerapkan model snowball throwing pada pembelajaran menulis resensi cerpen. 
Berdasarkan permasalahan tersebut, penulis berkeinginan untuk menerapkan model snowball throwing pada pembelajaran menulis resensi cerpen.

Untuk itu penulis tertarik menerapkan model Snowball throwing pada pembelajaran menulis resensi cerpen pada kelas XI IPA 1 di SMA Negerei 9 Kota Jambi dengan alasan sebagai berikut.

1. Pembelajaran keterampilan menulis akan menjadikan siswa terampil menulis.

2. Pembelajaran menulis resensi diajarkan pada kompetensi inti mengolah, menalar, dan menyaji dalam ranah konkret dan abstrak terkait dengan pengembangan dari yang dipelajarinya di sekolah secara mandiri, bertindak secara efektif dan kreatif, serta mampu menggunakan metode sesuai kaidah keilmuan dengan KD 4.17 mengkonstruksi sebuah resensi dari buku kumpulan cerpen atau novel yang sudah dibaca.

3. Tanpa keterampilan guru dalam menggunakan model pembelajaran maka pembelajaran sulit dicapai.

4. Model pembelajaran snowball throwing menjadi alternatif dalam pembelajaran menulis resensi cerpen.

5. Model pembelajaran snowball throwing memberikan kontribusi positif dalam proses pembelajaran.

Berdasarkan wawancara awal dengan guru Bahasa Indonesia di SMA Negeri 9 Kota Jambi bahwa untuk pembelajaran menulis resensi cerpen belum menggunakan model pembelajaran snowball throwing. Jadi, penulis beranggapan bahwa model ini cukup menarik untuk digunakan dalam pembelajaran menulis resensi cerpen. Oleh karena itu, penulis tertarik ingin melakukan penelitian lebih lanjut.
Berdasarkan latar belakang di atas, maka rumusan masalah dalam penelitian ini adalah bagaimanakah pengaruh model pembelajaran snowball throwing terhadap keterampilan menulis resensi cerpen siswa kelas XI IPA SMA Negeri 9 Kota Jambi Tahun Pelajaran 2018/2019?

Penelitian ini bertujuan untuk mendeskripsikan pengaruh penggunaan model pembelajaran snowball throwing terhadap keterampilan menulis resensi cerpen di kelas XI IPA SMA Negeri 9 Kota Jambi Tahun Pelajaran 2018/2019.

Hasil penelitian ini diharapkan memiliki manfaat teoretis sebagai berikut.

1. Hasil penelitian ini dapat bermanfaat sebagai pengembangan pembelajaran bahasa Indonesia khususnya pelajaran menulis resensi cerpen.

2. Hasil penelitian ini dapat menambah wawasan dan pengetahuan dalam hal penggunaan model pembelajaran snowball throwing.

Hasil dari penelitian ini diharapkan memiliki manfaat praktis sebagai berikut.

1. Bagi guru hasil penelitian ini diharapkan bermanfaat untuk dapat meningkatkan kemampuan dalam mengembangkan model pembelajaran.

2. Bagi siswa hasil penelitian ini diharapkan dapat meningkatkan keaktifan dalam pemecahan masalah di kehidupan sehari-hari serta meningkatkan keberanian siswa mengungkapkan ide, gagasan serta keterampilannya dalam menulis resensi cerpen.

3. Bagi penulis hasil penelitian ini diharapkan bermanfaat sebagai pengembangan wawasan sebagai calon guru bahasa Indonesia.

4. Bagi peneliti lainnya hasil penelitian ini diharapkan dapat memberi 
informasi awal atau sumber penelitian dengan bidang kajian yang berbeda.

\section{METODE PENELITIAN}

Penelitian ini menggunakan metode kuantitatif. Penelitian dengan pendekatan kuantitatif merupakan penelitian dengan data berupa angkaangka. Angka sebagai data penelitian akan dianalisis dengan menggunakan rumus statistik. "Pendekatan kuantitatif digunakan untuk menjawab rumusan masalah penelitian tersebut" (Sugiyono, 2012: 50).

Penelitian penggunaan model pembelajaran terhadap keterampilan menulis resensi cerpen di sekolah dengan mengukur pengaruh kemampuannya dapat dilakukan dengan pendekatan quasi eksperiment (eksperimen semu). Menurut Arikunto "Penelitian quasi eksperiment merupakan penelitian yang tidak memenuhi seluruh persyaratan yang ditetapkan dalam penelitian murni" (Arikunto, 2006:207). Penelitian quasi eksperiment ini dilaksanakan dengan menggunakan kelas kontrol dan kelas eksperimen. Desain penelitian quasi eksperiment mempunyai kelas kontrol dan kelas eksperimen tetapi tidak dapat berfungsi sepenuhnya untuk mempengaruhi pelaksanaan kuantitatif murni (Sugiyono, 2012:114). Dengan demikian hasil perhitungan penelitian dengan metode quasi eksperiment ini digunakan untuk menjawab tujuan penelitian ini.

Desain yang digunakan dalam ini penelitian ini adalah post-test. Dalam desain ini terdapat dua kelompok yakni kelompok eksperimen dan kelas kontrol. Pada kelas eksperimen diberikan perlakuan atau treatment $(\mathrm{X})$ dan pada kelompok perbandingan (kontrol) tidak diberikan perlakuan atau treatment (-).
Untuk mengetahui lebih jelas dapat dilihat pada tabel berikut.

Tabel 1. Desain Penelitian

\begin{tabular}{ccc}
\hline Kelompok & Perlakuan & Post-Test \\
\hline Eksperimen & $\mathrm{X}$ & $\mathrm{Q} 1$ \\
\hline Kontrol & - & $\mathrm{Q} 2$ \\
\hline
\end{tabular}

Penelitian ini dilaksanakan di SMA Negeri 9 Kota Jambi tahun pelajaran 2018/2019. Proses penelitian ini dilaksanakan dalam kurun waktu dua minggu.

Populasi adalah keseluruhan objek yang akan diteliti. "Populasi adalah wilayah generalisasi yang terdiri atas objek atau subjek yang mempunyai kualitas dan karakteristik tertentu yang diterapkan oleh peneliti untuk dipelajari dan kemudian ditarik kesimpulannya" (Sugiyono, 2012: 117). Populasi dalam penelitian ini adalah siswa kelas XI IPA SMA Negeri 9 Kota Jambi tahun pelajaran 2018/2019 dengan total jumlah keseluruhan yaitu 108 siswa.

Tabel 2. Populasi Penelitian

\begin{tabular}{ccc}
\hline No & Kelas & Jumlah Siswa \\
\hline 1. & XI IPA 1 & 36 \\
\hline 2. & XI IPA 2 & 36 \\
\hline 3. & XI IPA 3 & 36 \\
\hline \multicolumn{2}{c}{ Jumlah } & $\mathbf{1 0 8}$ \\
\hline
\end{tabular}

"Sampel adalah bagian dari jumlah dan karakteristik yang dimiliki oleh populasi tersebut" (Sugiyono, 2011: 81). Teknik yang dilakukan dalam pengambilan sampel yaitu menggunakan teknik purposive sampling yaitu teknik penentuan sampel dengan pertimbangan tertentu. Sampeldipilih dengan melihat karakteristik yang sama yaitu diajarkan oleh guru Bahasa Indonesia yang sama. Dengan melihat kriteria tersebut dapat ditentukan kelas eksperimen dan kelas kontrol. Kelas XI IPA 2 sebagai kelas 
eksperimen sedangkan kelas XI IPA 3 sebagai kelas kontrol.

Tabel 3. Sampel Penelitian

\begin{tabular}{|c|c|c|}
\hline No & Kelas & Jumlah Siswa \\
\hline 1. & XI IPA 2 & 36 \\
\hline 2. & XI IPA 3 & 36 \\
\hline & Jumlah & 72 \\
\hline
\end{tabular}

karakteristik dari individu atau objek yang hendak diteliti. "Variabel adalah segala sesuatu yang menunjukkan adanya variasi (bukan hanya satu macam) baik bentuknya, besarnya, kualitasnya, nilainya, warnanya dan sebagainya" (Mustikawan, 2008: 86). Variabel dalam penelitian ini adalah terdiri atas variabel bebas dan variabel terikat.

1. Variabel Bebas

"Variabel bebas adalah variabel yang menjelaskan atau mempengaruhi variabel lain. Variabel ini dapat disebut variabel independent" (Arikunto, 2006: 119). Dalam penelitian ini yang menjadi variabel bebas adalah model pembelajaran snowball throwing.

2. Variabel Terikat

"Variabel terikat adalah variabel yang dijelaskan atau dipengaruhi oleh variabel bebas. Variabel ini dapat juga disebut variabel dependent" (Arikunto, 2006: 119). Dalam penelitian ini yang menjadi variabel terikat adalah kemampuan menulis resensi cerpen.

Teknik pengumpulan data yang digunakan dalam penelitian ini adalah Teknik penugasan. "Penugasan adalah serentetan pertanyaan atau latihan yang digunakan untuk mengukur keterampilan, pengetahuan, kemampuan atau bakat yang dimiliki oleh individu atau kelompok" (Arikunto, 2006: 5). Dalam penelitian ini penulis memberikan tugas untuk menulis resensi cerpen. Pada kelas eksperimen penulis menerapkan model snowball throwing, sedangkan pada kelas kontrol menerapkan model konvensional. Setelah siswa mengerjakan tugas yang telah diberikan maka diperoleh hasil evaluasi mengenai pembelajaran menulis resensi cerpen pada kelas eksperimen dan kelas kontrol.

"Instrumen penelitian adalah suatu alat yang digunakan untuk mengukur fenomena alam maupun sosial yang diamati" (Sugiyono, 2013: 148). Penelitian ini menggunakan instrumen dalam bentuk tes penugasan keterampilan menulis resensi cerpen. Adapun komponen penilaian dalam keterampilan menulis menurut Nurgiyantoro (2013: 439) dapat dilihat pada tabel berikut.

Tabel 4. Unsur Penilaian Keterampilan Menulis Resensi Cerpen

\begin{tabular}{|c|c|c|}
\hline \multirow{2}{*}{ No. } & \multirow{2}{*}{ Aspek Penilaian } & Skor \\
\hline & & $\begin{array}{lllll}5 & 4 & 3 & 2 & 1\end{array}$ \\
\hline 1 & $\begin{array}{l}\text { Isi gagasan dalam } \\
\text { cerita }\end{array}$ & \\
\hline 2 & Struktur kalimat & \\
\hline 3 & Pilihan kata & \\
\hline 4 & Ejaan & \\
\hline
\end{tabular}

Keterangan skor:

$1=$ sangat tidak baik

2 = tidak baik

$3=$ cukup

$4=$ baik

$5=$ sangat baik

Dalam penelitian ini ada beberapa prasyarat yang perlu dilakukan sebelum melakukan analisis data agar kesimpulan yang diperoleh dapat memenuhi prasyarat.

Uji normalitas merupakan uji yang dilakukan sebagai prasyarat untuk melakukan analisis data. Uji normalitas bertujuan untuk menguji apakah data dari tiap-tiap variabel penelitian berdistribusi 
normal atau tidak. Untuk menguji normalitas menggunakan rumus ChiSquare (Chi-Kuadrat) menurut Sugiyono (2012: 107) dengan rumus sebagai berikut.

$$
x^{2}=\sum_{i=1}^{k} \frac{(f 0-f 2)^{2}}{f h}
$$

Keterangan:

$x^{2}=$ Chi-Kuadrat

$f_{0} \quad=$ frekuensi yang diobservasi

$f_{h} \quad$ frekuensi yang diharapkan

Uji homogenitas digunakan untuk memperlihatkan bahwa dua atau lebih kelompok data sampel berasal dari populasi yang memiliki variasi yang sama. uji homogentas dikenakan pada data hasil post-test dari kelompok eksperimen dan kelompok kontrol. Untuk mengukur homogenitas varians dari dua kelompok data, digunakan rumus uji $\mathrm{F}$ sebagai berikut.

$F=\frac{\text { varian terbesar }}{\text { varian terkecil }}($ Sugiyono,2012: 276)

Kriteria yang digunakan untuk mengambil kesimpulan apabila Fhitung lebih besar dari $\mathrm{F}_{\text {tabel }}$ pada taraf signifikan $\alpha=0,05$ maka memiliki varian yang homogen. Akan tetapi apabila bila Fhitung lebih besar dari $F_{\text {tabel }}$ pada taraf signifikan $\alpha=0,05$ maka varian tidak homogen.

Pengujian hipotesis dalam penelitian ini digunakan untuk membuktikan ada tidaknya pengaruh penggunaan model pembelajaran Snowball throwing terhadap kemampuan menulis cerpen siswa kelas XI IPA SMA Negeri 9 Kota Jambi tahun pelajaran 2018/2019.

Proses pengujian hipotesis untuk menjawab permasalahan pada rumusan masalah dilakukan dengan menggunakan rumusan sebagai berikut.

$$
\text { Thitung }=\frac{x 1-x 2}{\sqrt{\left\{\frac{(n 1-1) s_{1}^{2}+(n 2-1) s_{2}^{2}}{n 1+n 2-2}\right\}+\left\{\frac{1}{n 1}+\frac{1}{n 2}\right\}}}
$$

$S_{1}^{2}=$ standar deviasi kelas eksperimen

$S_{2}^{2}=$ standar deviasi kelas kontrol

$\mathrm{n}_{1}=$ jumlah siswa kelas eksperimen

$\mathrm{n}_{2}=$ jumlah siswa kelas kontrol

Hasil perhitungan data dengan

rumus uji $t$ tersebut kemudian disesuaikan dengan harga dalam $\mathrm{T}_{\text {tabel }}$ pada taraf $\alpha=0,05$. Jika $\mathrm{T}_{\text {hitung }}$ lebih besar dari $\mathrm{T}_{\text {tabel }}$ maka diasumsikan $\mathrm{H}_{\mathrm{a}}$ diterima. Demikian pula sebaiknya, jika $\mathrm{T}_{\text {hitung }}$ lebih kecil dari $\mathrm{T}_{\text {tebel }} \mathrm{H}_{\mathrm{a}}$ ditolak.

\section{HASIL DAN PEMBAHASAN}

Berdasarkan hasil pembelajaran di kedua kelas tersebut maka diperoleh perbedaan nilai pada kelas eksperimen dan kelas kontrol seperti pada tabel berikut.

Tabel 5. Hasil Pembelajaran Menulis Resensi Cerpen

\begin{tabular}{ccccc}
\hline Nilai & $\begin{array}{c}\text { Nilai } \\
\text { Tertinggi }\end{array}$ & $\begin{array}{c}\text { Nilai } \\
\text { Terendah }\end{array}$ & $\begin{array}{c}\text { Simpangan } \\
\text { Baku }\end{array}$ & $\begin{array}{c}\text { Rata- } \\
\text { rata }\end{array}$ \\
\hline Kontrol & 90 & 60 & 9,290 & 75,8 \\
\hline Eksperimen & 95 & 65 & 8,308 & 83 \\
\hline
\end{tabular}

Berdasarkan tabel di atas terlihat bahwa penggunaan model pembelajaran snowball throwing berpengaruh terhadap hasil belajar siswa. Hal ini terlihat pada nilai tertinggi pada pembelajaran kelas eksperimen adalah 95 lebih besar dari nilai tertinggi yang didapat pada kela kontrol sebesar 90. Nilai terendah yang didapat pada kelas ekperimen adalah 65 lebih tinggi dari nilai terendah yang didapat pada kelas kontrol sebesar 60 . Nilai simpangan baku pada postes lebih kecil dari nilai simpangan baku pada kelas kontrol, artinya rentang nilai tertinggi dan terendah pada kelas kontrol tidak terlalu jauh dengan nilai simpangan 
baku kelas kontrol 9,290 sedangkan simpangan baku pada kelas ekperimen 8,308 .

Selain itu, dari nilai rata-rata juga menunjukkan model pembelajaran snowball throwing memberikan pengaruh yang baik terhadap kemampuan menulis resensi cerpen. Nilai rata-rata pada kelas eksperimen lebih baik dari kelas kontrol dengan nilai rata-rata kelas eksperimen sebesar 83 sedangkan nilai rata-rata kelas kontrol hanya sebesar 75,8.

Berdasarkan analisis data yang telah dilakukan, diketahui bahwa nilai rata-rata siswa yang diajar dengan menggunakan model pembelajaran snowball throwing adalah 83. Sementara untuk nilai rata-rata setiap aspek kemampuan menulis resensi cerpen diketahui sebagai berikut. Pertama, pada aspek isi gagasan dalam cerita diperoleh nilai rata-rata 4,5 dengan predikat baik Kedua, pada aspek struktur kalimat diperoleh nilai rata-rata 4,2 dengan predikat baik. Ketiga, pada aspek pilihan kata diperoleh nilai rata-rata 3,9 dengan predikat cukup. Keempat, pada aspek ejaan diperoleh nilai rata-rata 4 dengan predikat baik. Berikut akan dijelaskan nilai kelas kontrol.

Berdasarkan analisis data yang telah dilakukan, diketahui bahwa nilai rata-rata siswa yang diajar tanpa menggunakan model pembelajaran snowball throwing adalah 75,8. Sementara untuk nilai rata-rata setiap aspek kemampuan menulis resensi cerpen diketahui sebagai berikut. Pertama, pada aspek isi gagasan dalam cerita diperoleh nilai rata-rata 4,4 dengan predikat baik Kedua, pada aspek struktur kalimat diperoleh nilai rata-rata 3,65 dengan predikat cukup. Ketiga, pada aspek pilihan kata diperoleh nilai ratarata 3,68 dengan predikat cukup.
Keempat, pada aspek ejaan diperoleh nilai rata-rata 3,4 dengan predikat cukup. Untuk melihat bagaimana pelaksanaan penelitian dengan memberikan perlakuan berupa model pembelajaran snowball throwing pada kelas eksperimen dilakukan dengan uji persyarat sebagai berikut.

\section{Uji Normalitas}

Berdasarkan nilai yang telah didapat, dilakukan uji normalitas. Uji normalitas dilakukan dengan bantuan komputer program spss shapiro-wilk. Berdasarkan uji normalitas yang telah dilakukan diperoleh nilai $\mathrm{p}$ kelas kontrol sebesar $0,057>0,05$ dan nilai $\mathrm{p}$ kelas eksperimen sebesar 0,095>0,05 (taraf signifikansi). Dengan demikian dapat disimpulkan bawah data kedua kelas tersebut berdistribusi normal.

\section{Uji Homogenitas}

Setelah melakukan uji normalitas penulis melakukan uji homogenitas. Uji homogenitas dilakukan untuk mengetahui apakah varian kedua kelas homogen atau tidak. Berdasarkan uji homogenitas yang telah dilakukan diperoleh nilai $\mathrm{F} 0,439>$ dari tafar signifikansi $(\alpha=0,05)$. Dengan demikian kedua kelas berasal dari populasi yang memiliki varian yang sama atau homogen.

\section{Pengujian Hipotesis}

Berdasarkan hasil uji normalitas dan homogenitas, diperoleh hasil bahwa kedua sampel berasal dari populasi yang berdisribusi normal dan kedua varians populasi homogen, maka selanjutnya data dapat dilakukan uji hipotesis. Pengujian hipotesis dilakukan untuk mengetahui apakah penggunaan model snowball throwing berpengaruh terhadap kemampuan menulis resensi cerpen. Dalam penelitian ini uji hipotesis 
menggunakan uji t. Hipotesis statistik penelitian ini adalah $H_{o}: \mu_{1}=\mu_{2}$ dan $H_{a}$ $: \mu_{1} \geq \mu_{2}$. Dari hasil perhitungan uji t, diperoleh nilai $t_{\text {hitung }}$ sebesar 4,045 . Untuk nilai $t_{\text {tabel }}$ di peroleh dari tabel $t$ dengan dk 70 dan taraf signifikansi $(\alpha) 0,05$ yaitu sebesar 2,000. Dengan membandingkan nilai $t_{\text {hitung }}$ dan $t_{\text {tabel }}$ diperoleh $t_{\text {hitung }}>t_{\text {tabel }}$, ini berarti $H_{o}$ ditolak dan $H_{a}$ diterima.

Berdasarkan nilai siswa kelas XI

IPA SMA Negeri 9 Kota Jambi pada pembelajaran menulis resensi cerpen dengan menggunakan model snowball throwing diperoleh nilai rata-rata kelas eksperimen sebesar 83, sedangkan nilai rata-rata kelas kontrol sebesar 75,8. Berdasarkan perhitungan tersebut terdapat perbedaan hasil antara kelas eksperimen dan kelas kontrol, hal ini merupakan pengaruh dari model snowball throwing.

Penilaian pada aspek isi gagasan dalam cerita di peroleh nilai dengan jumlah 156 dengan rata-rata 4,5 untuk kelas eksperimen, sedangkan pada kelas kontrol diperoleh nilai dengan jumlah 156 dengan rata-rata 4,4. Penilaian aspek struktur kalimat diperoleh nilai dengan jumlah 150 dengan rata-rata 4,2 untuk kelas eksperimen, sedangkan pada kelas kontrol diperoleh nilai dengan jumlah 128 dengan rata-rata 3,6. Penilaian pada aspek pemilihan kata diperoleh nilai dengan jumlah 142 dengan rata-rata 3,9 untuk kelas eksperimen, sedangkan pada kelas kontrol diperoleh nilai dengan jumlah 129 dengan rata-rata 3,68. Penilaian pada aspek ejaan di peroleh nilai dengan jumlah 144 dengan rata-rata 4 untuk kelas eksperimen, sedangkan pada kelas kontrol diperoleh nilai dengan jumlah 118 dengan rata-rata 3,4. Setelah menjelaskan hasil penilaian ada setiap aspeknya, penulis akan menjelaskan hasil uji prasyarat dan uji hipotesis.
Pengujian prasyarat dilakukan dengan dua macam pengujian yaitu uji normalitas dan uji homogenitas. Pengujian ini dilakukan untuk mengetahui apakah kedua sampel tersebut berdistribusi normal dan memiliki varian yang homogen. Berdasarkan uji normalitas diperoleh hasil sebesar $0,057>0,05$ (taraf signifikan) untuk kelas eksperimen dan $0,095>0,05$ (taraf signifikan) untuk kelas kontrol. Dari hasil kedua sampel tersebut dapat diketahui bahwa sampel tersebut berdistribusi normal.

Selanjutnya dilakukan uji homogenitas yang hasilnya adalah $\mathrm{F}$ $0,439>$ dari tafar signifikansi $(\alpha=0,05)$ (taraf signifikan). Hasil tersebut menunjukkan bahwa kedua sampel tersebut berasal dari varian yang homogen. Setelah melakukan uji prasyarat maka langkah selanjutnya yaitu uji hipotesis. Berdasarkan perhitungan statistik, maka diperoleh hasil $t_{\text {hitung }}=$ $2.514>\mathrm{t}_{\text {tabel }}=1.671$ yang menunjukkan bahwa $\mathrm{H}_{\mathrm{a}}$ diterima.

Hasil penelitian ini menunjukkan bahwa hasil pembelajaran menulis resensi cerpen menggunakan model snowball throwing lebih baik dari pada hasil pembelajaran menulis resensi cerpen dengan menggunakan model konvensional. Sehingga dalam pembelajaran menulis resensi cerpen, model snowball throwing dapat diterapkan karena mempengaruhi hasil belajar siswa.

Berdasarkan pengujian prasyarat didapat bahwa kedua sampel berdisribusi normal dan kedua varians populasi homogen, maka selanjutnya data dapat dilakukan uji hipotesis. Pengujian hipotesis dilakukan untuk mengetahui apakah penggunaan model snowball throwing berpengaruh terhadap kemampuan menulis resensi cerpen. 
Dalam penelitian ini uji hipotesis menggunakan uji t. Hipotesis statistik penelitian ini adalah $H_{o}: \mu_{1}=\mu_{2}$ dan $H_{a}$ $: \mu_{1} \geq \mu_{2}$. Dari hasil perhitungan uji $\mathrm{t}$ (terlampir), diperoleh nilai $t_{\text {hitung }}$ sebesar 4,045. Untuk nilai $t_{\text {tabel }}$ di peroleh dari tabel $\mathrm{t}$ dengan $\mathrm{dk} 70$ dan taraf signifikansi $(\alpha)$ 0,05 yaitu sebesar 2,000 . Dengan membandingkan nilai $\mathrm{t}_{\text {hitung }}$ dan $\mathrm{t}_{\text {tabel }}$ diperoleh $\mathrm{t}_{\text {hitung }}>\mathrm{t}_{\text {tabel }}$, ini berarti $H_{o}$ ditolak dan $H_{a}$ diterima.

\section{SIMPULAN}

Berdasarkan analisis dan
pembahasan hasil penelitian dapat penulis simpulkan bahwa penggunaan model snowball throwing berpengaruh terhadap kemampuan menulis resensi cerpen. Hal ini dibuktikan dengan nilai rata-rata kelas eksperimen yang lebih tinggi dibanding kelas kontrol. Nilai ratarata kelas eksperimen adalah sebesar 83 sedangkan kelas kontrol sebesar 75,8.

Pengaruh model snowball throwing juga dapat dibuktikan dengan pengujian hipotesis yang sebelumnya dilakukan uji prasyarat. Uji prasyarat dilakukan dengan dua pengujian yaitu uji normalitas dan uji homogenitas. Uji normalitas menunjukkan nilai probabilitas kelas kontrol sebesar $0,057>0,05$ dan nilai probabilitas kelas eksperimen sebesar 0,095>0,05 (taraf signifikansi). Dengan demikian, dapat disimpulkan bawah data kedua kelas tersebut berdistribusi normal. Begitu juga dengan uji homogenitas yang menjukkan bahwa kedua kelas tersebut memiliki varian yang homogen dengan nilai sebesar $0,439>$ dari tafar signifikansi $(\alpha$ $=0,05)$. Dengan demikian kedua kelas berasal dari populasi yang memiliki varian yang sama atau homogen.

Berdasarkan hasil uji prasyarat tersebut, dilakukan uji hipotetsis yang menunjukkan bahwa $t_{\text {hitung }}=4,045>t_{\text {tabel }}$
$=4,045$ yang mengartikan bahwa $\mathrm{H}_{\mathrm{a}}$ diterima. Dari hasil tersebut maka dapat dikatakan bahwa model snowball throwing berpengaruh terhadap kemampuan siswa dalam menulis resensi cerpen.

\section{Saran}

Berdasarkan kesimpulan yang telah diperoleh, maka dapat dikemukakan beberapa saran sebagai berikut.

1. Bagi guru, agar dapat menggunakan model snowball throwing dalam pembelajaran keterampilan menulis resensi cerpen dalam upaya menggali kreativitas dan menumbuhkan kemampuan siswa dalam menulis.

2. Bagi sekolah, agar dapat mengembangkan model pembelajaran yang tepat guna bagi guru untuk mencapai kompetensi yang diharapkan.

3. Bagi peneliti berikutnya agar dapat melakukan penelitian dengan menggunakan model snowball throwing dalam pembelajaran lain.

\section{DAFTAR PUSTAKA}

Arikunto, Suharsimi. (2006). Prosedur Penelitian Suatu Pendidikan Praktik. Jakarta: Rineka Cipta.

Mustikawan, Alfin. (2008). Metode Penelitian. Malang: Biro Penelitian LKP2M UIN Malang.

Nurgiyantoro, Burhan. (2013_. Penilaian Pembelajran Bahasa Berbasis Kompetensi. Yogyakarta: Badan Percetakan Fakultas Ekonomi Universitas Negeri Yogyakarta.

Puspita, Tara. Gafar, Abdoel. Rofii, Afif. (2019). Pengaruh Penggunaan Model Pembelajaran Think Pair Share terhadap Keterampilan Menulis Surat Pribadi Siswa Kelas VII SMP Negeri 5 Kota Jambi. Aksara: Jurnal Ilmiah 
Pendidikan Bahasa dan Sastra Indonesia Vol. 3 No. 1 April 2019.

http://aksara.unbari.ac.id/index.ph p/aksara/article/viewFile/104/59

Rahima, A., \& Zahar, E. (2018). Peningkatan Akses Pendidikan dalam rangka mengahadapi Pelaksanaan Wajib Belajar 12 Tahun di Kab. Tanjab Timur Tahun 2008. Jurnal Ilmiah Universitas Batanghari Jambi, 11(1), 25-33.

Rofii, A., Murtadho, F., Rahmat, A. (2018) "model of ContextualBased Academic Writing Learning Module (R\&D At Faculty of Teacher Training And Education Universitas Batanghari Jambi)" English Review: Journal of English Education, vol. 6, no. 2 pp 51-60. Doi: $\quad 10.25134 /$ erjee.v6i2.1242. (https://www.journal.uniku.ac.id/i ndex.php/ERJEE/article/view/124 2

Rofii, Afif., Fathiaty, Murtadho., Rahmat, Aceng. (2019 A). Needs Analysis: A Learning Model for CTL-Based Academic Writing. Proceedings of the Eleventh Conference on Applied Linguistics (conaplin 2018) https://www.atlantispress.com/procedings/conaplin18/125911424

Rofii, Afif., Murtadho, Fathiaty., Rahmat, Aceng. (2019 B). The Perception of Lecturers and Students on Learning Model of Contextual-Based Academic Writing. Proceeding First International Conference on Advances in Education, Humanities, and Language. Malang: (https://eudl.eu/doi.418/eai.23-32019.2284915

Saminanto. (2010). Model-model Pembelajaran. Bandung: Alfabeta.

Setia, R. B. J., Zahar, E., \& Rahima, A. (2018). Penggunaan Media Lagu Pop dalam Pembelajaran Menulis Cerpen Realis Siswa Kelas IX A SMP Negeri 9 Kota Jambi Tahun Pelajaran 2016/2017. Aksara: Jurnal Ilmiah Pendidikan Bahasa dan Sastra Indonesia, 2(1), 183191.

Sugiyono. (2012). Metode Penelitian Pendidikan: Pendekatan Kuantitatif, Kualitatif dan $R \& D$. Bandung: Alfabeta.

Tarigan, Henry Guntur. (2008). Menulis sebagai Suatu Keterampilan Berbahasa. Bandung: Penerbit Angkasa. 